\title{
Niche convergence suggests functionality of the nocturnal fovea
}

\author{
Gillian L. Moritz ${ }^{*}$, Amanda D. Melin ${ }^{2}$, Fred Tuh Yit $\mathrm{Yu}^{3}$, Henry Bernard ${ }^{4}$, Perry S. Ong ${ }^{5}$ and \\ Nathaniel J. Dominy ${ }^{1,6}$
}

\author{
Department of Biological Sciences, The Class of 1978 Life Sciences Center, Dartmouth College, Hanover, NH, USA \\ 2 Department of Anthropology, Washington University, St. Louis, MO, USA \\ ${ }^{3}$ Research and Education Division, Zoology and Entomology, Kota Kinabalu, Malaysia \\ ${ }^{4}$ Institute for Tropical Biology and Conservation, Universiti Malaysia Sabah, Kota Kinabalu, Malaysia \\ ${ }^{5}$ Institute of Biology, University of the Philippines Diliman, Quezon City, Philippines \\ ${ }^{6}$ Department of Anthropology, Dartmouth College, Hanover, NH, USA
}

Edited by:

Sharif A. Taha, University of Utah Medical School, USA

\section{Reviewed by:}

Andreas Reichenbach, University of Leipzig, Germany

Luiz Carlos L. Silveira, Universidade

Federal do Pará, Brazil

\section{${ }^{*}$ Correspondence:}

Gillian L. Moritz, Department of

Biological Sciences, The Class of 1978

Life Sciences Center, Dartmouth

College, 78 College Street, Hanover, NH 03755, USA

e-mail: gillian.l.moritz@dartmouth.edu
The fovea is a declivity of the retinal surface associated with maximum visual acuity. Foveae are widespread across vertebrates, but among mammals they are restricted to haplorhine primates (tarsiers, monkeys, apes, and humans), which are primarily diurnal. Thus primates have long contributed to the view that foveae are functional adaptations to diurnality. The foveae of tarsiers, which are nocturnal, are widely interpreted as vestigial traits and therefore evidence of a diurnal ancestry. This enduring premise is central to adaptive hypotheses on the origins of anthropoid primates; however, the question of whether tarsier foveae are functionless anachronisms or nocturnal adaptations remains open. To explore this question, we compared the diets of tarsiers (Tarsius) and scops owls (Otus), taxa united by numerous anatomical homoplasies, including foveate vision. A functional interpretation of these homoplasies predicts dietary convergence. We tested this prediction by analyzing stable isotope ratios that integrate dietary information. In Borneo and the Philippines, the stable carbon isotope compositions of Tarsius and Otus were indistinguishable, whereas the stable nitrogen isotope composition of Otus was marginally higher than that of Tarsius. Our results indicate that species in both genera consumed mainly ground-dwelling prey. Taken together, our findings support a functional interpretation of the many homoplasies shared by tarsiers and scops owls, including a retinal fovea. We suggest that the fovea might function similarly in tarsiers and scops owls by calibrating the auditory localization pathway. The integration of auditory localization and visual fixation during prey detection and acquisition might be critical at low light levels.

Keywords: fovea centralis, stable isotopes, Otus lempiji, Otus megalotis, Tarsius bancanus, Tarsius syrichta, diet, visual predation

\section{INTRODUCTION}

The fovea centralis, or fovea, is an avascular declivity of the retinal surface. It is aligned with the visual axis of the eye and contains a disproportionately high density of photoreceptors. The optics of foveae are an enduring interest (Walls, 1937; Weale, 1966; Locket, 1992; Ross, 2004) because the fovea has greater spatial resolving power than other retinal specialization (Inzunza et al., 1989; Moore et al., 2012). A fovea is therefore the site of maximal visual acuity among vertebrates (Walls, 1942; Polyak, 1957; Provis etal., 2013). The energetic cost of highacuity vision is presumed to be high due to the large volume of cortical tissue devoted to foveal vision (Perry and Cowey, 1985; Silveira etal., 1989; Hendrickson, 2005). Indeed, the tandem concept of sensory specialization and cortical overrepresentation, or magnification, is now practically idiomatic: gymnotid and mormyrid fish have electrosensory "foveas"; (Castelló et al., 2000; Bacelo et al., 2008); echolocating bats have acoustic "foveas" (Neuweiler, 2003); and some haptic species have tactile or somatosensory "foveas" (Pettigrew and Frost, 1985;
Catania and Remple, 2004; Hoffmann et al., 2004; Mancini et al., 2013).

Foveal vision is assumed to serve a vital adaptive function and the comparative biology of foveate taxa has proven instructive (review: Ross, 2004). Foveae are widespread among diurnal vertebrates, but among mammals they are restricted to haplorhine primates (tarsiers, monkeys, apes, and humans). This taxonomic distribution suggests that foveae are an adaptation to diurnal or photopic conditions. The strongest support for this view stems from taxa that shifted or reversed their primary activity pattern. For example, geckos are secondarily nocturnal and a fovea is normally absent (Ross, 2004); however, some 15 genera have reverted to diurnality and regained foveate vision (Tansley, 1960; Röll, 2001). Multiple tertiary origins of foveae within Gekkonidae suggest that the selective advantages of high-acuity vision are strongest under photopic conditions. Yet some nocturnal birds and many deep-sea fish possess rod-dominant foveae (Bowmaker and Martin, 1978; Collin, 1999; Collin et al., 2000), raising the possibility that a nocturnal fovea is not always a scotopic anachronism. 


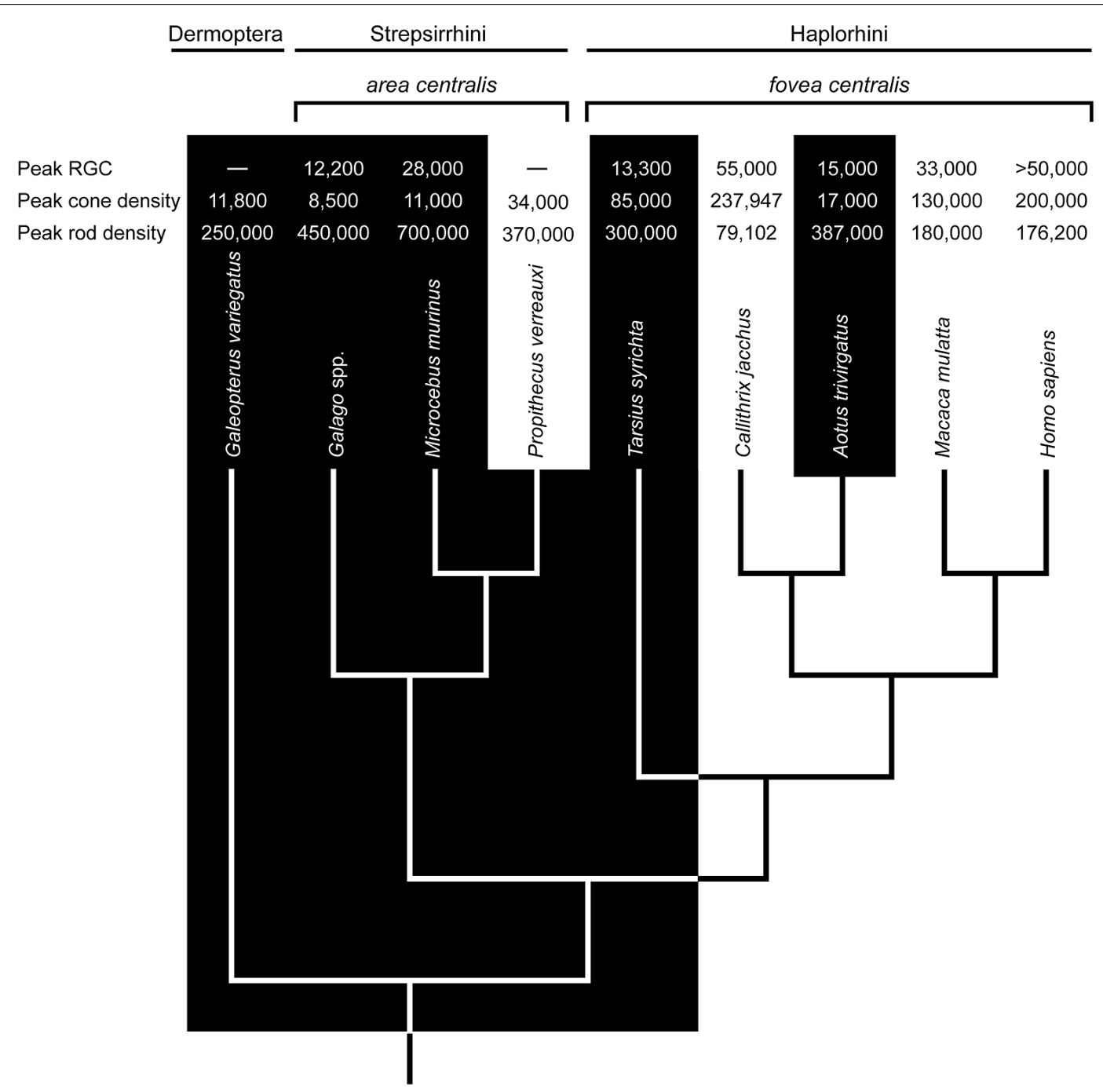

FIGURE 1 |The phyletic relationships of select primates and the sister taxon Dermoptera (the Sunda colugo, Galeopterus variegatus). The distinction between nocturnal (black zone) and diurnal (white zone) activity patterns is strongly associated with variation in retinal ganglion cell (RGC) counts $\left(\mathrm{mm}^{-2}\right)$, cone densities $\left(\mathrm{mm}^{-2}\right)$, and rod densities $\left(\mathrm{mm}^{-2}\right)$ in the area centralis or fovea centralis (data sources: Webb and Kaas, 1976; Perry and Cowey, 1985; Curcio etal., 1990; Wikler and Rakic, 1990; Silveira etal., 1993; Ogden, 1994; Wilder etal., 1996; Hendrickson etal., 2000; Dkhissi-Benyahya etal., 2001; Peichl etal.,
2001: Ross, 2004: Tetreault etal., 2004; Finlay etal., 2008; Moritz etal. 2013). Ancestral character states based in part on these values suggest a diurnal ancestry for Tarsius and Aotus; and, by extension, stem anthropoids (e.g., Ross, 2000; Williams etal., 2010). Accordingly, the foveae of Tarsius and Aotus are most likely vestigial traits. A problem with this view is evident in the densities of RGCs, cones, and rods. Relative to Tarsius, the retina of Aotus has advanced further toward a nocturnal phenotype despite a substantially younger vintage of 5-20 million years (see text).
The question of whether nocturnal foveae are adaptations or functionless vestiges is central to the study of primate evolution. Currently, two haplorhine taxa - tarsiers (Tarsius) and night monkeys (Aotus) - are nocturnal, and the former sits at a crucial position in the primate phylogenetic tree (Figure 1). Tarsiers are the basal crown haplorhine primate and their fovea has long informed hypotheses on the origins of anthropoid primates (Treacher Collins, 1922; Elliot Smith, 1928; Le Gros Clark, 1959; Cartmill, 1980; Martin, 1990; Ross, 2000, 2004; Martin and Ross, 2005; Williams etal., 2010). And yet, Aotus has been the model taxon for understanding foveal degeneracy.

\section{NOCTURNAL HAPLORHINES AND THE CONCEPT OF FOVEAL DEGENERACY}

The retina of Aotus has been studied since the 1870s (Polyak, 1957; Ogden, 1994; Silveira et al., 2001), and a rod-dominated fovea is either absent (Woollard, 1927; Detwiler, 1941; Jones, 1965; Ferraz de Oliveira and Ripps, 1968), shallow and rudimentary (Kolmer, 1930; Polyak, 1957; Wolin and Massopust, 1967; Silveira et al., 1993), or present in 10\% of individuals (Ogden, 1994). Walls (1953) viewed this variation as evidence of functional degeneracy. Webb and Kaas (1976) averred, reporting a shallow fovea and displaced ganglion cells; they also suggested that a degenerate fovea is functionally comparable to an area centralis, the 
retinal specialization of strepsirrhine primates (Rohen and Castenholz, 1967; Wolin and Massopust, 1970). Indeed, the densities of rods and cones in the foveae of Aotus azarae and Aotus trivirgatus resemble those in the area centralis of Galago garnetti, a lorisid primate (Wikler and Rakic, 1990; Finlay et al., 2008). The notion of foveal degeneracy in Aotus, together with the absence of a tapetum lucidum, is widely interpreted as evidence of a diurnal ancestry, as illustrated in Figure 1.

A shift to nocturnality could have occurred $\sim 20$ Ma on the basis of phylogenetic affinities with Tremacebus, which was plausibly nocturnal (Kay and Kirk, 2000; Kay et al., 2004; Ross et al., 2007). Recent molecular phylogenies are compatible with this view, suggesting that the stem ancestor of Aotus diverged from diurnal Cebidae $19.3 \mathrm{Ma}$ (Perelman et al., 2011), whereas crown Aotus diversified $\sim 5.5$ to $4.6 \mathrm{Ma}$ (Menezes et al., 2010; Ruiz-García et al., 2011). Thus, the antiquity of nocturnality in the aotine lineage is between $\sim 5$ and 20 million years. This span was evidently sufficient to favor degenerate foveae among other distinctive attributes, such as relatively enlarged eyes and orbits (Kirk, 2006; Ross and Kirk, 2007), disabling mutations of the short-wavelengthsensitive-1 (SWS1) opsin gene (Jacobs et al., 1996; Levenson et al., 2007), rod photoreceptors with an inverted nuclear architecture (Joffe et al., 2014), and large numbers of P retinal ganglion cells (Silveira et al., 1994) with high rod convergence to both $\mathrm{M}$ and $\mathrm{P}$ cells (Yamada et al., 2001). These traits differentiate Aotus from all other monkeys and are strongly convergent with nocturnal mammals; hence, the aotine visual system is almost certainly a nocturnal derivation.

The functional anatomy of the tarsier retina is more challenging to interpret (Ross, 2004). Early studies of spectral tarsiers (Tarsius spectrum) failed to detect a fovea (Woollard, 1925, 1926), whereas recent investigations report the uniform presence of roddominant, concave-sided (concaviclivate) foveae (Hendrickson et al., 2000; Hendrickson cited in Ross, 2004). Similar foveae are present in Philippine tarsiers (Tarsius syrichta; Polyak, 1957; Wolin and Massopust, 1967), but variable among Bornean tarsiers (Tarsius bancanus; Castenholz, 1965; Castenholz, 1984). On the surface, these findings point to an Aotus-like state of foveal degeneracy; however, the fovea of Tarsius is deeper, less variable, and associated with much higher cone densities (50,000$85,000 \mathrm{~mm}^{-2}$; Hendrickson et al., 2000; Hendrickson cited in Ross, 2004) than that of Aotus (5000-17,000 $\mathrm{mm}^{-2}$; Wikler and Rakic, 1990; Finlay et al., 2008). Another difference concerns the SWS1 opsin gene; it is intact among tarsiers (Tan et al., 2005) and a low rate of non-synonymous to synonymous substitutions is consistent with strict purifying selection (Kawamura and Kubotera, 2004).

Modest foveal degeneracy and a functional SWS1 opsin gene have been interpreted as evidence of a recent transition to nocturnality (Tan et al., 2005). Indeed, two recent findings support this premise. First, the rods of T. spectrum have a nuclear architecture that is strongly associated with diurnality (Joffe et al., 2014). Second, molecular evidence suggests that the ancestral crown tarsier possessed a cone opsin polymorphism that enabled trichromatic vision (Melin et al., 2013). The antiquity of this character trait is uncertain, with crown divergence dates ranging from $\sim 18.6 \mathrm{Ma}$ (Springer et al., 2012) to $\sim 13$ to $9 \mathrm{Ma}$ (Melin et al., 2013), but multiple independent losses of trichromatic vision appear to have occurred in the past 5 million years (Melin et al., 2013). Such findings suggest a relatively recent history of diurnality; and yet, the fossil record is a testament to committed nocturnality. The hyperenlarged orbits of Tarsius eoceanus (Middle Eocene), Tarsius sirindhornae (Middle Miocene), and living tarsiers are most parsimoniously interpreted as evidence of continuous nocturnality for at least 45 million years (Rossie et al., 2006; Chaimanee et al., 2011). These discrepant lines of evidence are difficult to reconcile.

The foveae and rod architecture of tarsiers could be adaptations to non-photopic conditions; and, hence not necessarily vestiges of a diurnal ancestor. Melin et al. (2013) hypothesized that the hyperenlarged eyes and foveate color vision of ancestral crown tarsiers (and potentially stem tarsiers and anthropoid primates), evolved to support visual predation under dim (mesopic) light levels such as twilight or bright moonlight. These light conditions are predicted to support cone-mediated color vision (Melin et al., 2012) and favor enlarged eyes for greater visual sensitivity in the absence of a tapetum lucidum (Cartmill, 1980). This attempt at consilience is laudable but difficult to test.

\section{COMPARATIVE FUNCTIONAL ECOLOGY OF THE NOCTURNAL FOVEA}

It is challenging for humans to observe how tarsiers discern vertebrate and invertebrate prey; they appear to integrate and alternate between auditory and visual cues depending on ambient conditions and prey type (Niemitz, 1979, 1984; MacKinnon and MacKinnon, 1980; Gursky, 2000, 2002; Dagosto et al., 2003). Such a specialized niche is assumed to have few competitors, a concept that reinforces the perception of tarsiers as "living fossils" in a state of ecological stasis (Jablonski, 2003). However, observations of the Sunda scops owl (Otus lempiji), a tarsier-sized faunivore (90-140 g), suggest a comparable niche (König and Weick, 2008; Figure 2). Potential niche convergence has attracted attention due to the many homoplasies that unite tarsiers and scops owls, such as (i) hyperenlarged eyes that protrude from the orbit (Figures 3A,B); (ii) orbit-induced displacement of the olfactory tract, which itself is unusually long; (iii) a loss of ocular mobility that corresponds with increased cervical mobility (Figures 3C,D); (iv) acute directional hearing; (v) enlarged semicircular canals; and, (vi) derived feeding morphologies for perforating prey (Niemitz, 1985, 2010; Menegaz and Kirk, 2009). Niemitz (1985) interpreted this suite of character traits as an adaptation to sit-and-wait ambush predation at low light levels. Evidence of dietary overlap would support this hypothesis and potentially shed light on yet another shared homoplasy, the fovea.

Within Strigiformes, there is mixed evidence for foveae in the family Tytonidae (barn and bay owls). For example, a fovea can be present (Oehme, 1961) or absent in barn owls (Tyto alba; Wathey and Pettigrew, 1989; Lisney etal., 2012). In the family Strigidae ("typical" owls) rod-dominant, concaviclivate foveae are uniformly present (Wood, 1917; Rochon-Duvigneaud, 1943; Oehme, 1961; Fite, 1973; Fite and Rosenfield-Wessels, 1975; Lisney et al., 2012); and at least one species, the tawny owl (Strix aluco), has a fovea with three cone classes (Martin and Gordon, 1974; Bowmaker and Martin, 1978). Strix aluco demonstrates that foveate trichromatic vision can exist in tandem with a nocturnal eye and orbit (Hall and Ross, 2007; Ross et al., 2007; Hall, 

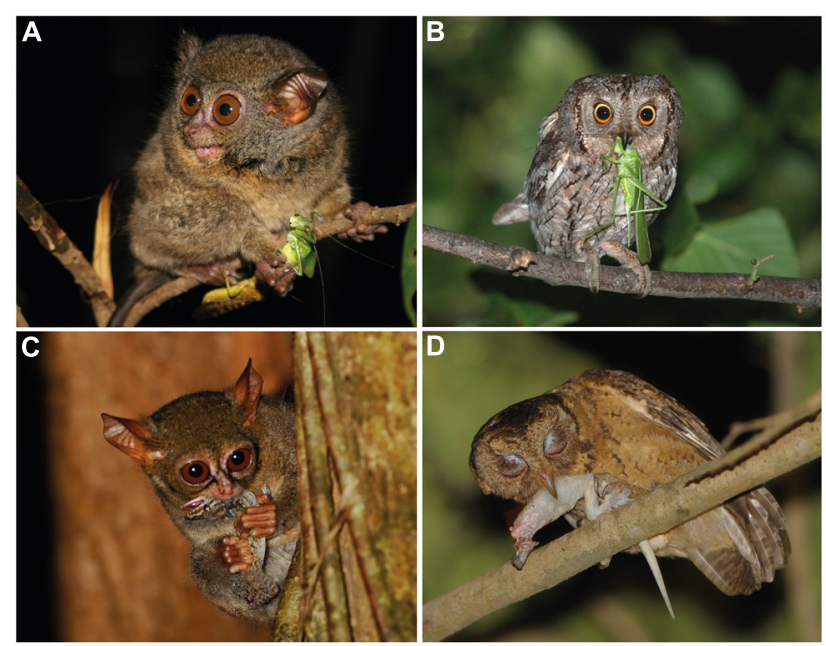

FIGURE 2 | (A) Orthopteran insects such as katydids are a common prey item in the diet of tarsiers (photograph of Tarsius lariang by Stefan Merker, reproduced with permission). (B) Orthopteran insects are also consumed by scops owls (photograph of Otus scops by Clément and Julien

Pappalardo, reproduced with permission). (C) Tarsiers also consume geckos (photograph of T. spectrum by David J. Slater, reproduced with permission). (D) In Singapore, geckos are reported to be the most common food item in the diet of O. lempiji (Lok etal., 2009; photograph by Tiah Khee Lee, reproduced with permission).

2008). Furthermore, at least two strigid species, the scops owl (Otus scops) and little owl (Athene noctua), can make chromatic discriminations at low light levels (Parejo et al., 2010; Avilés and Parejo, 2013). The retention of foveate color vision in strigids has been associated with foraging under mesopic conditions (Avilés and Parejo, 2013), a view that reinforces the possibility of tarsiers behaving similarly.

\section{STUDY DESIGN}

A controlled experimental approach is preferable for testing foveal function; however, the mortality rate of captive tarsiers is unacceptably high (Fitch-Snyder, 2003). Accordingly, we conceived a study premised on abductive reasoning: if tarsiers and scops owls are observed to have similar diets, then the fovea that unites them can be interpreted as a functional dietary trait. A weakness of abduction is that a conclusion can remain false following verification of the initial premise. Even still, such reasoning has practical value when information is limited. Here we focus on data available in the tissues of wild-caught animals. The stable isotope ratios in these tissues can be used to quantify prior behavioral observations of dietary convergence.

Stable isotope ratios are a practical tool for quantifying the diets of difficult-to-observe animals. The isotopic niche of a species is often based on ratios of carbon $\left({ }^{13} \mathrm{C}:{ }^{12} \mathrm{C}\right.$ or $\left.\delta^{13} \mathrm{C}\right)$ and nitrogen $\left({ }^{15} \mathrm{~N}:{ }^{14} \mathrm{~N}\right.$ or $\left.\delta{ }^{15} \mathrm{~N}\right)$ isotopes in a two-dimensional " $\delta$-space" (Newsome et al., 2007). For example, the $\delta^{13} \mathrm{C}$ values of animals in a savanna-woodland can vary because most plants fix atmospheric $\mathrm{CO}_{2}$ via two photosynthetic pathways. The $\delta^{13} \mathrm{C}$ values of $\mathrm{C}_{3}$ and $\mathrm{C}_{4}$ plants are ca. $-28 \%$ (range -21 to $-35 \%$ ) and $-14 \%$ o (range -12 to $-16 \%$ o), respectively (O'Leary, 1988), a difference that persists in the isotopic composition of primary and secondary consumers. In a tropical forest, the isotopic baseline of plants varies to lesser extent, although factors such as canopy cover, relative humidity, light availability, tree height, and soil moisture can drive variation in $\delta^{13} \mathrm{C}$ values (Heaton, 1999; Amundson et al., 2003; Marshall et al., 2007). For example, $C_{3}$ plants under sunny conditions are ${ }^{13} \mathrm{C}$-enriched (high $\delta^{13} \mathrm{C}$ values: -21 to $-27 \%$ ), whereas those in the understory are ${ }^{13} \mathrm{C}$-depleted (low $\delta^{13} \mathrm{C}$ values: $<-31 \%$ ) due to the recycling of $\mathrm{CO}_{2}$ (Kohn, 2010). This "canopy effect," or gradient of decreasing $\delta^{13} \mathrm{C}$ values from the canopy to the understory (Vogel, 1978; Medina and Minchin, 1980; van der Merwe and Medina, 1991), is reflected in the isotopic composition of consumers (Schoeninger, 2010), although with a small offset due to enrichment effects. In general, the $\delta^{13} \mathrm{C}$ values of herbivores are $2-3 \%$ more positive than their diet, whereas herbivore-to-faunivore trophic enrichment can range from 0.2 to 4\%o (on the basis of keratin: DeNiro and Epstein, 1978; Roth and Hobson, 2000; Sponheimer et al., 2003; Fox-Dobbs et al., 2007; Hyodo et al., 2010; Crowley et al., 2011). Thus, $\delta^{13} \mathrm{C}$ values can discriminate trophic position as well as the vertical stratum of foraging within a habitat (Voigt, 2010; Rex et al., 2011), including the dipterocarp forests of southeast Asia (Kawanishi et al., 2012).

Variation in $\delta^{15} \mathrm{~N}$ is a dietary indicator due to the systematic retention of ${ }^{15} \mathrm{~N}$ at each trophic level (Gannes et al., 1997). Thus increasing $\delta^{15} \mathrm{~N}$ values are associated with trophic "steps." A step can range from 1.3 to $5 \%$, but $3 \%$ is typical (DeNiro and Epstein, 1981; Schoeninger, 1985; Roth and Hobson, 2000; Post, 2002; Fox-Dobbs et al., 2007). In the dipterocarp forests of Borneo, the $\delta^{15} \mathrm{~N}$ values of predators are ca. 2.6\% higher than those of omnivores, $3 \%$ o higher than those of herbivores, and 3.7\%o higher than those of detritivores (Hyodo et al., 2010). These results suggest that variation in $\delta^{15} \mathrm{~N}$ can discriminate trophic levels in the habitats used by tarsiers and scops owls, although the isotopic baseline of tree leaves in northern Borneo can vary slightly as function of soil $\mathrm{N}$ availability (Kitayama and Iwamoto, 2001) and disturbance history (Woodcock et al., 2012). This variation is manifested in the tissues of secondary consumers. For example, Nakagawa et al. (2007) showed that the hair of omnivorous rodents in open, degraded forests were ${ }^{15} \mathrm{~N}$-enriched (higher $\delta^{15} \mathrm{~N}$ values) relative to conspecifics in primary forest, whereas $\delta^{15} \mathrm{~N}$ values did not differ between treeshrews and squirrels inhabiting different forest types.

Thus Tarsius and Otus are predicted to have similar isotopic niches, or overlapping $\delta^{13} \mathrm{C}$ and $\delta^{15} \mathrm{~N}$ values. Affirmation of this prediction would be consistent with functional interpretations of the many anatomical homoplasies shared between these two taxa, including the retinal fovea.

\section{MATERIALS AND METHODS SAMPLE ACOUISITION AND PREPARATION}

We sampled the contour feathers of Sunda scops owls (Otus lempiji, formerly O. bakkamoena lempiji; $n=8$ ) and Philippine scops owls (Otus megalotis, formerly O. bakkamoena megalotis; $n=11$; taxonomy follows König and Weick, 2008). We also sampled hair from the shoulders of Bornean tarsiers (T. bancanus; $n=6$ ) and Philippine tarsiers (T. syrichta; $n=28$ ). The specimens, all wild-caught adults, were chosen on the basis 

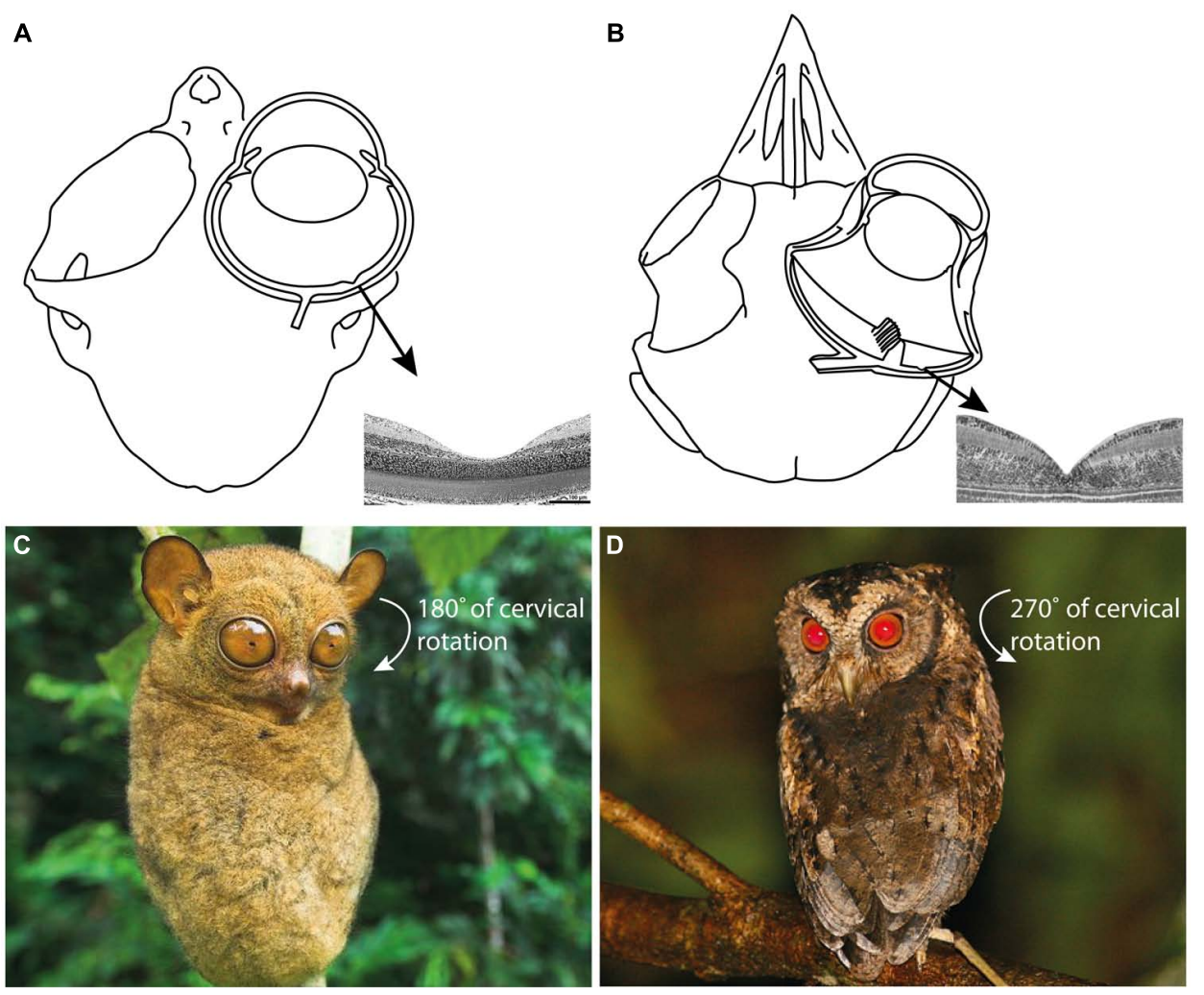

FIGURE 3 I (A) The skull and eye of Tarsius bancanus (modified from Castenholz, 1984; Ross, 2004) together with the fovea of T. spectrum (modified from Hendrickson etal., 2000). (B) The skull, eye, and fovea of a composite strigiform (modified from Fite, 1973; Menegaz and Kirk, 2009). Because ocular mobility is constrained by the hyperenlarged eyes of tarsiers and scops owls, an extraordinary degree of cervical rotation is necessary to enable rapid prey localization and fixation. (C) The increased cervical mobility of tarsiers allows them to rotate their head $180^{\circ}$ in azimuth (Castenholz, 1984; photograph of T. bancanus by Nick Garbutt, reproduced with permission). (D) Owls can rotate their head $270^{\circ}$ in azimuth (Harmening and Wagner, 2011; photograph of 0 . lempiji by Paul B. Jones, reproduced with permission). Extreme head rotation is thought to enhance the sit-and-wait ambush mode of predation common to tarsiers and scops owls (Niemitz, 1985). of maximum overlapping provenience (Figure 4). The majority of specimens are accessioned in the American Museum of Natural History, the Field Museum of Natural History, the Kinabalu National Park Museum, and the Universiti Malaysia Sabah Museum (Appendix 1). We supplemented these samples with hair from a wild population of T. syrichta in the vicinity of Motorpool, Tubod, Surigao del Norte, Mindanao, Philippines $\left(09^{\circ} 38^{\prime} \mathrm{N}\right.$; $\left.125^{\circ} 33^{\prime} \mathrm{E}\right)$. These tarsiers $(n=12)$ were hand-caught and anaesthetized as part of a larger study of their sensory ecology (Ramsier et al., 2012). For measurements of $\delta^{13} \mathrm{C}$ and $\delta^{15} \mathrm{~N}$ in keratin, 23 feathers or 10-15 strands of hair were cleaned of debris using ethanol, sonicated in ultrapure water, and washed 1-2 times in petroleum ether. The samples were then cut into small fragments $(\sim 1 \mathrm{~mm})$ and weighed $(500 \pm 15 \mu \mathrm{g})$ into precombusted tin capsules.

\section{ANALYTICAL PROCEDURES}

Isotope ratios are presented as $\delta$ values, where $\delta=1000$ (( $\mathrm{R}$ sample/R standard $)-1$ ) and $\mathrm{R}={ }^{13} \mathrm{C} /{ }^{12} \mathrm{C}$ or $\mathrm{R}={ }^{15} \mathrm{~N} /{ }^{14} \mathrm{~N}$; reference standards are Vienna Pee Dee Belemnite (VPDB) for carbon and atmospheric $\mathrm{N}_{2}$ for nitrogen. Units are expressed as parts per thousand $(\%)$. The dried samples were combusted and analyzed with a Thermo-Chemical Elemental Analyzer (TCEA) interfaced with a Delta Plus XP isotope ratio mass spectrometer (IRMS, Thermo Finnigan, Bremen, Germany) located in the Stable Isotope Laboratory, University of California, Santa Cruz. The analytical precision $( \pm 1 \mathrm{SD})$ for $\delta^{13} \mathrm{C}$ and $\delta^{15} \mathrm{~N}$ was $0.3 \%$ and $0.05 \%$, respectively, based on four International Atomic Energy Agency (IAEA) acetanilide replicates.

A potential confounding factor is associated with the steady global decrease in the ${ }^{13} \mathrm{C}$ content of atmospheric $\mathrm{CO}_{2}$ due primarily to fossil fuel burning during the past 150 years (the Suess effect; Indermühle et al., 1999). The total magnitude of this change is ca. $1.5 \%$ o (Long et al., 2005), but the effects within 5-10 year intervals are relatively small (ca. $0.1 \%$ ). To account for this variation in atmospheric $\mathrm{CO}_{2}$, which in turn is reflected in the tissues of plants and consumers, we applied conservative time-dependent correction factors of $-0.004 \%$ or $-0.02 \%$ per year to samples from specimens collected between 1860 and 1965 and between 1965 and 2010, respectively (Francey et al., 1999; Keeling et al., 2005).

Another confounding factor stems from geographic and temporal variation in soil $\mathrm{N}$ availability, both natural (Högberg, 1997; Kitayama and Iwamoto, 2001) and anthropogenic (Kendall et al., 


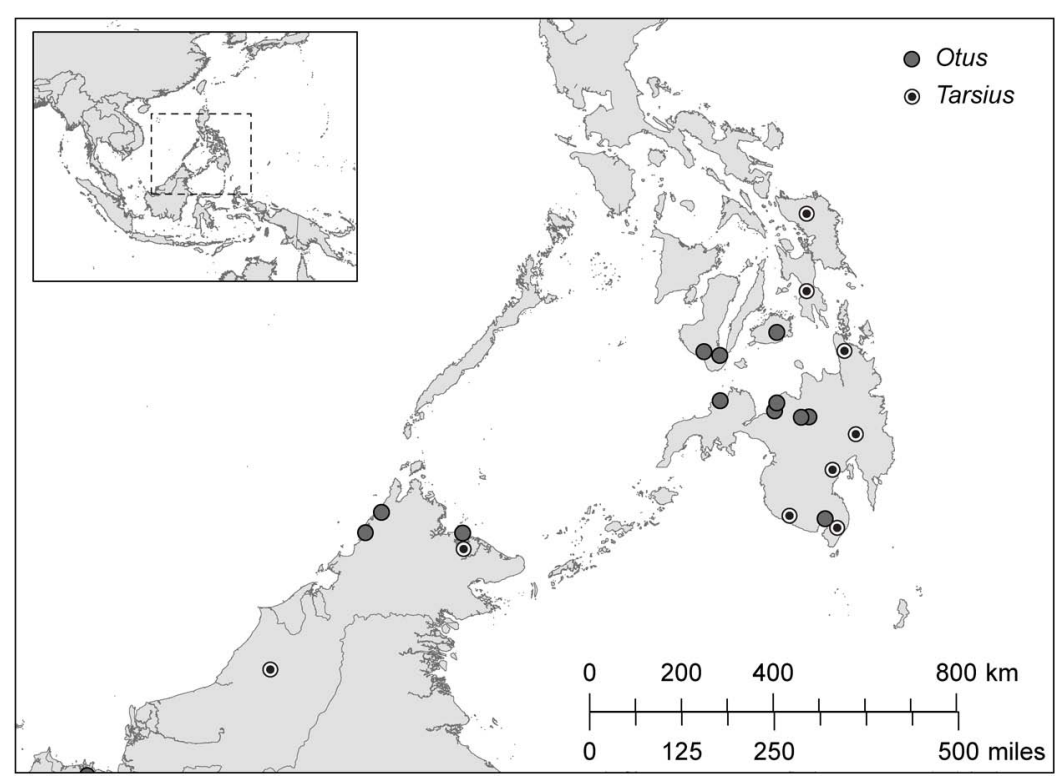

FIGURE 4 |The distribution of sampling localities in Borneo (Otus lempiji and Tarsius bancanus) and in Philippines (O. megalotis and T. syrichta).

2007; Hietz et al., 2011), and the potential for spatial autocorrelation of $\delta^{15} \mathrm{~N}$ values. To explore this first possibility, we averaged all samples from a given site and calculated Moran's index of spatial autocorrelation. We detected no evidence of spatial autocorrelation among sample sites (Otus sites: $n=13$, Moran's $I=0.23$, $z=1.60, p=0.11$; Tarsius sites: $n=10$, Moran's $I=-0.19$, $z=-0.45, p=0.65$ ), although the semivariograms are potentially uninformative due to the small number of samples spread over a relatively large spatial scale. Each $\delta^{15} \mathrm{~N}$ value is therefore assumed to have statistical independence for assessing diet.

\section{STATISTICAL ANALYSES}

We performed all statistical tests in R version 2.14.1 (R Development Core Team, 2011). As some of our data violated the assumptions of parametric statistical analysis, we used nonparametric Wilcoxon rank sum (two-sample) and KruskalWallis $\chi^{2}$ (multiple comparison) tests to assess whether the carbon and nitrogen isotope compositions differentiate sympatric taxa of Tarsius and Otus. For all normally distributed data, comparisons of significance were investigated using Welch's Two Sample $t$-tests. The significance for all tests was set at $\alpha=0.05$.

\section{RESULTS}

Appendix 1 summarizes the raw and time-dependent corrections to $\delta^{13} \mathrm{C}$. The mean $\pm \mathrm{SD}$ of all time-corrected samples was $-23.76 \pm 1.6 \%$ (range: $-27.80 \%$ o to $-17.41 \%$ ). Within Borneo, the time-corrected $\delta^{13} \mathrm{C}$ values of O. lempiji (mean: $22.87 \pm 1.7 \%$ ) were ca. $1.95 \%$ o greater than those of $T$. bancanus (mean: $-24.82 \pm 0.2 \%$ ), but the difference did not reach statistical significance (Wilcoxon $W=38$; $p=0.08$; Figure 5). Similarly, in the Philippines, the time-corrected $\delta^{13} \mathrm{C}$ values of O. megalotis (mean: $-23.33 \pm 2.5 \%$ ) were ca. $0.62 \%$ o greater than those of $T$.

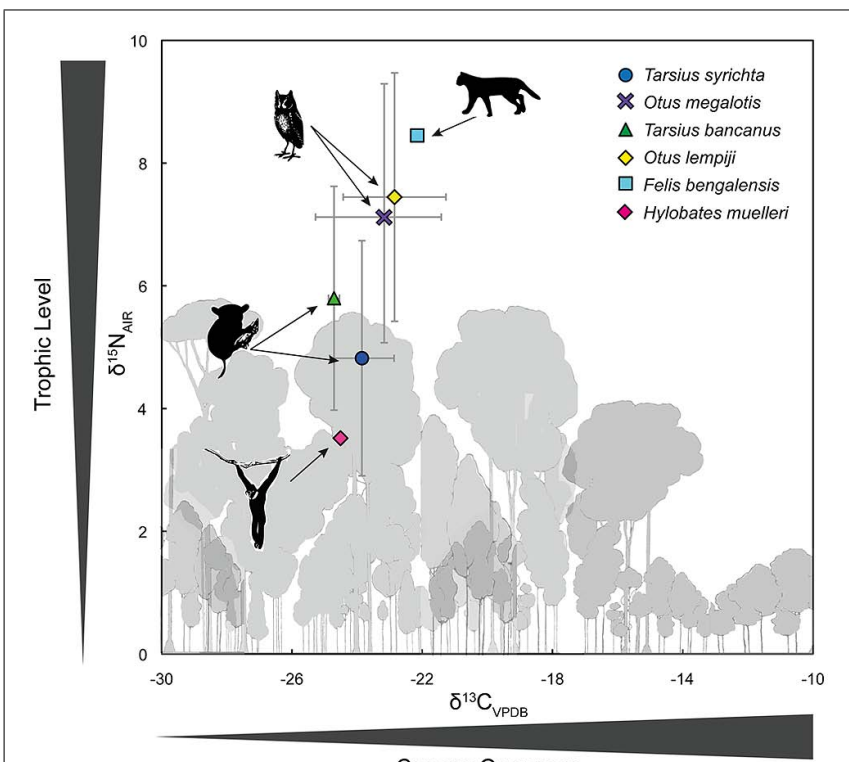

Canopy Openness

FIGURE 5 | Bivariate plot of $\delta^{13} \mathrm{C}$ and $\delta^{15} \mathrm{~N}$ values (mean $\pm 1 \mathrm{SD}$ ) in the keratin of Bornean tarsiers (Tarsius bancanus), Philippine tarsiers (T. syrichta), Sunda scops owls (Otus lempiji), and Philippine scops owls (O. megalotis). To illustrate an approximate full dietary trophic step, the keratin-derived $\delta^{13} \mathrm{C}$ and $\delta^{15} \mathrm{~N}$ values of a frugivore (Müller's Bornean gibbon, Hylobates muelleri) and a predator of vertebrates (leopard cat, Felis bengalensis) from Sabah, northern Borneo are also plotted.

syrichta (mean: $-23.95 \pm 1.1 \%$ ), but the difference did not reach significance (Wilcoxon $W=196 ; p=0.198$; Figure 5). Intrageneric comparisons revealed differences between the two species of Tarsius ( $W=36, p=0.03$ ) but not the two species of Otus $\left(t_{16.82}=0.46, p=0.648\right)$. 
Appendix 1 summarizes the raw values $\delta^{15} \mathrm{~N}$. The mean $\pm \mathrm{SD}$ of all samples was $5.79 \pm 2.2 \%$ (range: $2.39-11.37 \%$ ). Within Borneo, the $\delta^{15} \mathrm{~N}$ values of O. lempiji (mean: $7.45 \pm 1.7 \%$ ) were ca. $1.65 \%$ oreater than those of T. bancanus (mean: $5.80 \pm 1.8 \%$ ), but the difference did not reach statistical significance (Wilcoxon $W=36 ; p=0.142$; Figure 5). The effect size of this analysis is sufficient to rule out a Type II error (Cohen's $d=0.95$ ). Within the Philippines, the $\delta^{15} \mathrm{~N}$ values of $O$. megalotis (mean: $7.04 \pm 2.3 \%$ ) were ca. $2.22 \%$ greater than those of T. syrichta (mean: $4.82 \pm 1.9 \%$ ), indicating significant ${ }^{15} \mathrm{~N}$-enrichment (Wilcoxon $W=239, p=0.008$; Figure 5); however, the samples from T. syrichta collected in 2010 exhibited systematically low $\delta^{15} \mathrm{~N}$ values, perhaps due to recent anthropogenic changes to the landscape (e.g., Fox-Dobbs et al., 2012). When we calculated the mean of these samples, log-transformed all $\delta^{15} \mathrm{~N}$ values, and controlled for specimen year in a general model, there was no statistical difference between $O$. megalotis and T. syrichta $(t=-0.28, p=0.781)$. Intrageneric comparisons revealed no differences between the two species of Tarsius $\left(t_{7.43}=1.19, p=0.271\right)$ or the two species of Otus $\left(t_{17}=0.44, p=0.664\right)$.

Figure 5 also illustrates the larger food web by including the $\delta^{13} \mathrm{C}$ and $\delta^{15} \mathrm{~N}$ values of a primary consumer, the frugivorous Müller's gibbon (Hylobates muelleri; $n=1$ ), and a predator of vertebrates, the leopard cat (Felis bengalensis; $n=1$ ). The isotopic differences $(\Delta)$ between these taxa $\left(\Delta^{13} \mathrm{C}: 2.36 \% ; \Delta^{15} \mathrm{~N}: 4.93 \%\right.$ ) approximate a full trophic step, albeit a rather large one. Hyodo et al. (2010) reported a similar $\Delta^{13} \mathrm{C}$ value of $2.4 \%$, but a smaller $\Delta{ }^{15} \mathrm{~N}$ value of $3.0 \%$ o between herbivores and predators in Lambir National Park, Sarawak, Borneo. In any case, the magnitude of the isotopic difference $(\Delta)$ between O. megalotis and T. syrichta $\left(\Delta^{15} \mathrm{~N}=2.22\right)$ is much less than that between Felis and Hylobates $\left(\Delta^{15} \mathrm{~N}=4.93 \%\right.$ o).

\section{DISCUSSION}

In many respects, tarsiers are not owls, but almost (Niemitz, 2010, p. 953)

Our results demonstrate isotopic overlap: the $\delta^{13} \mathrm{C}$ values of Otus and Tarsius were indistinguishable, whereas the $\delta^{15} \mathrm{~N}$ values of Otus were often higher than those of Tarsius. The low and comparable $\delta^{13} \mathrm{C}$ values indicate use of the same stratum (the forest floor), a foraging pattern that agrees well with behavioral observations. The differences in $\delta^{15} \mathrm{~N}$ values - a pattern that was a trend in Borneo and temporally variable in the Philippines are potentially instructive because they indicate a subtle degree of prey partitioning. Yet the magnitude of the isotopic difference $(\Delta)$ between $O$. megalotis and T. syrichta $\left(\Delta^{15} \mathrm{~N}=2.22\right)$ is much less than that between Felis and Hylobates $\left(\Delta^{15} \mathrm{~N}=4.93 \%\right.$; Figure 5), suggesting limited partitioning of invertebrate and vertebrate prey (discussed below). However, Hyodo et al. (2010) reported a herbivore-predator $\Delta^{15} \mathrm{~N}$ of $3.0 \%$ on the basis of a much larger data set from Sarawak. Taken together, our isotopic results demonstrate that Otus and Tarsius occupy similar dietary niches, although a trend toward ${ }^{15} \mathrm{~N}$-enrichment among scops owls, particularly O. megalotis, suggests some prey partitioning.

For instance, it is plausible that tarsiers consume relatively few insect-eating squamates. Such an interpretation conflicts with early accounts, which stressed the central importance of geckos to the diets of T. bancanus and T. syrichta (captivity: Wharton, 1950; Harrison, 1963; wild: Fogden, 1974). However, our findings corroborate those of Davis (1962), who found a preponderance of large orthopteran insects in the stomachs of seven wild-caught Bornean tarsiers and Niemitz (1984), who observed T. bancanus under seminatural conditions in Sarawak. Niemitz reported that vertebrates (squamates, birds) represented $<11 \%$ of 133 successful predation events. In Sulawesi, tarsiers seldom consume vertebrates (MacKinnon and MacKinnon, 1980; Tremble et al., 1993; Gursky, 2007a), but geckos can represent $4.2 \%$ of the diet (by mass) of tarsiers in captivity (Dahang et al., 2008).

A discrepancy between the foraging behaviors of wild and captive tarsiers might indicate a release from predation or competition. Perhaps in the absence of scops owls, tarsiers can shift their foraging preference to vertebrate prey. Still, recent studies of captive tarsiers in the United States report that T. bancanus ignores anoles (Anolis carolinensis) in favor of crickets, whereas T. syrichta exhibits the reverse pattern (Haring and Wright, 1989; Roberts and Kohn, 1993). These mixed responses to a North American anole are difficult to interpret, and they illustrate the challenge of studying the foraging adaptations of a small nocturnal visual predator. In general, our isotopic results agree well with field observations, although these are sparse - invertebrates appear to represent the great majority prey objects consumed by tarsiers.

Another possible explanation for the ${ }^{15} \mathrm{~N}$-enrichment of Otus stems from the consumption of dung-eating (scatophagous) coleopterans:

"Food is usually sought near the ground... in villages (Otus lempiji) habitually hunts nocturnal insects attracted to cow dung or poultry droppings around houses. Some stomachs examined were crammed with cockroaches (Blattidae) and a particular type of black dung beetle (Scarabidae). The Sumatran (Minangklabau) name for this owl is kuas cirit ayam, which means 'fowl's-excrement owl'" (König and Weick, 2008, p. 274).

The sobriquet "excrement owl" is potentially instructive. Animal waste is often enriched in ${ }^{15} \mathrm{~N}$ due to the volatilization of ${ }^{15} \mathrm{~N}$-depleted ammonia, and subsequent oxidation of the residual waste material can result in nitrate with high $\delta^{15} \mathrm{~N}$ values (Kendall et al., 2007). For example, cow dung is typically ${ }^{15} \mathrm{~N}$-enriched $(\sim 2.3 \%$ o) relative to diet (Steele and Daniel, 1978). This effect could be amplified in the dipterocarp forests of Borneo, where extended periods of protein limitation can result in ${ }^{15} \mathrm{~N}$-enriched urine among large mammals, e.g., orangutans (Vogel et al., 2012). Thus, dung-eating (scatophagous) insects should be enriched in ${ }^{15} \mathrm{~N}$ relative to their plant-eating (phytophagous) counterparts, and the relative ${ }^{15} \mathrm{~N}$-enrichment of Otus could reflect a greater proportion of scatophagous coleopterans or nocturnal squamates, or both, in the diet. To discriminate the relative contributions of these putative food sources, it would be useful to collect food samples and perform a Bayesian multiple source isotopic mixing model (e.g., Yeakel et al., 2009; Rutz et al., 2010).

A final possibility - that scops owls occasionally consume tarsiers - seems unlikely. Niemitz (1984) reported that Otus failed to induce an obvious response among Bornean tarsiers, and MacKinnon and MacKinnon (1980, p. 375) observed that spectral tarsiers "paid no attention to an owl Ninox sp. sitting and calling 
a few yards above them.” However, Gursky (2003a) reported that predator-naive infants (aged one and two months) distanced themselves from the calls of raptors (including the Sulawesi owl, Tyto rosenbergii and the speckled boobook, Ninox punctulata) and minimized movement in response to models of an ochre-bellied boobook (Ninox ochracea) and spotted kestrel (Falco moluccensis). Among adult tarsiers, the kestrel elicited the twin antipredator behaviors of mobbing and alarm calling during $47 \%$ of encounters, indicating that adults recognized it as a threat (Gursky, 2007b). The fact that no similar behaviors were directed toward owls suggests that Otus is an unlikely predator of Tarsius.

\section{THE TARSIER FOVEA - FUNCTIONLESS VESTIGE OR NOCTURNAL ADAPTATION?}

In a report to the Zoological Society of London, the preeminent anatomist Grafton Elliot Smith described his charge to Wilfrid Le Gros Clark, who, in 1920, was appointed Principal Medical Officer to the Government of Sarawak. "I impressed upon him," wrote Elliot Smith (1921, p. 184), "the importance of studying the retina of living or freshly-killed examples of Tarsius... a surviving member of the Eocene family from which our own simian ancestors were derived." This advice from a mentor to a student rings as true today as it did a century ago; and, although the retina of Tarsius has since been examined in detail (Woollard, 1925, 1926, 1927; Polyak, 1957; Castenholz, 1965; Wolin and Massopust, 1967; Castenholz, 1984; Hendrickson et al., 2000; Tetreault et al., 2004), it continues to yield surprises (Joffe et al., 2014). And still, an open question remains: is the fovea a functionless vestige or a nocturnal adaptation? (Ross, 2004).

Our isotopic results are germane to this question insofar as they provide empirical evidence of food competition between scops owls and tarsiers. Although this finding entails some resource partitioning, it fails to refute the functional interpretation of the many homoplasies that unite Otus and Tarsius (Niemitz, 1985), including, very likely, the fovea. This evidence of anatomical and dietary convergence raises the possibility of parallel learning mechanisms. Perhaps a central function of the fovea is to calibrate the auditory system during development, as shown in barn owls (T. alba). In other words, foveate vision may guide sound localization by verifying the accuracy of auditory orientation to a sound source (Knudsen and Knudsen, 1985; Knudsen, 2002). This concept of vision-mediated or "supervised" learning (Knudsen, 1994) is compelling - Philippine tarsiers have extraordinary hearing abilities (Ramsier et al., 2012) and foveate vision could be a contributing factor to the evolution and development of their auditory localization pathway (Heffner and Heffner, 1992). Behavioral observations of tarsiers have long stressed the dual importance of auditory localization and visual fixation during prey detection and acquisition (Niemitz, 1979).

If instructed learning in the auditory localization pathway is at least partly dependent on foveate vision, then a unified representation of visual and auditory sensory stimuli was potentially a central factor in the enduring success of Tarsius. The initial calibration or subsequent recalibration of this system might require cone activation under non-scotopic conditions. This hypothesis could account for both the high number of cones in the fovea of Tarisus (relative to Aotus; Figure 1) and the phenomenon of lunar philia (increased activity under moonlight) among spectral tarsiers (Gursky, 2003b). It might also explain why the photoreceptors of tarsiers have attributes normally associated with mesopic or photopic light levels (Melin et al., 2013; Joffe et al., 2014). Taken together, the natural history of tarsiers represents a model system for studying how experience might shape the functional organization of the brain and the ensuing functional ecology of an animal.

\section{ACKNOWLEDGMENTS}

We thank A. F. Amir, D. Andreasen, J. W. Chipman, B. E. Crowley, A. J. Cunningham, L. D. Dagsaan, T. K. Lee, A. Lok, A. U. Luczon, C. Sendall, and C. V. Williams for practical support in the field and lab. We thank the Mamanwa for their hospitality and knowledge of tarsiers and the National Commission on Indigenous People for facilitating Prior Informed Consent (PIC) for the collection of samples. In Malaysia, permission to sample and export tissues from collections was granted by the Sabah Biodiversity Council [permit nos. JKM/MBS.1000-2/2(26) and JKM/MBS.1000-2/3(30)]. In the Philippines, permission to harvest and export tissues was granted by the Protected Areas and Wildlife Bureau, Department of Environment and Natural Resources (permit no. R13-2010-003). Samples from CITES Appendix I-listed species were imported under certificate no. 09US684773/9. We thank L. R. Heaney, W. T. Stanley, and D. Willard at the Field Museum of Natural History and D. P. Lunde and P. Sweet at the American Museum of Natural History for permission to collect tissue samples. Our protocols (nos. 11-06-07AT and 11-09-02AT) were approved by the Dartmouth Institutional Animal Care and Use Committee. Finally, we thank the David and Lucile Packard Foundation for funding (Fellowship in Science and Engineering no. 2007-31754).

\section{SUPPLEMENTARY MATERIAL}

The Supplementary Material for this article can be found online at: http://www.frontiersin.org/journal/10.3389/fnint.2014.00061/ abstract

\section{REFERENCES}

Amundson, R., Austin, A. T., Schuur, E. A. G., Yoo, K., Matzek, V., Kendall, C., et al. (2003). Global patterns of the isotopic composition of soil and plant nitrogen. Global Biogeochem. Cycles 17, 1031. doi: 10.1029/2002GB001903

Avilés, J. M., and Parejo, D. (2013). Colour also matters for nocturnal birds: owlet bill coloration advertises quality and influences parental feeding behaviour in little owls. Oecologia 173, 399-408. doi: 10.1007/s00442-013-2625-2628

Bacelo, J., Engelmann, J., Hollmann, M., Von Der Emde, G., and Grant, K. (2008). Functional foveae in an electrosensory system. J. Comp. Neurol. 511, 342-359. doi: $10.1002 / \mathrm{cne} .21843$

Bowmaker, J. K., and Martin, G. R. (1978). Visual pigments and colour vision in a nocturnal bird, Strix aluco (tawny owl). Vision Res. 18, 1125-1130. doi: 10.1016/0042-6989(78)90095-0

Cartmill, M. (1980). "Morphology, function, and evolution of the anthropoid postorbital septum," in Evolutionary Biology of the New World Monkeys and Continental Drift, eds R. L. Ciochon and A. B. Chiarelli (New York: Plenum Press), 243-274.

Castelló, M. E., Aguilera, P. A., Trujillo-Cenóz, O., and Caputi, A. A. (2000). Electroreception in Gymnotus carapo: pre-receptor processing and the distribution of electroreceptor types. J. Exp. Biol. 203, 3279-3287.

Castenholz, A. (1984). "The eye of Tarsius," in Biology of Tarsiers, ed. C. Niemitz (Stuttgart: Gustav Fischer Verlag), 303-318.

Castenholz, E. (1965). Über die struktur der netzhautmitte bei primaten. $Z$. Zellforsch. 65, 646-661. doi: 10.1007/bf00342589 
Catania, K. C., and Remple, F. E. (2004). Tactile foveation in the star-nosed mole. Brain Behav. Evol. 63, 1-12. doi: 10.1159/000073755

Chaimanee, Y., Lebrun, R., Yamee, C., and Jaeger, J.-J. (2011). A new Middle Miocene tarsier from Thailand and the reconstruction of its orbital morphology using a geometric-morphometric method. Proc. Biol. Sci. 278, 1956-1963. doi: $10.1098 /$ rspb.2010.2062

Collin, S. P. (1999). "Behavioural ecology and retinal cell topography," in Adaptive Mechanisms in the Ecology of Vision, eds S. Archer, M. B. Djamgoz, E. Loew, J. C. Partridge, and S. Vallerga. (Dordrecht: Kluwer Academic Publishers), 509-535. doi: 10.1007/978-94-017-0619-3_17

Collin, S. P., Lloyd, D. J., and Wagner, H.-J. (2000). Foveate vision in deep-sea teleosts: a comparison of primary visual and olfactory inputs. Phil. Trans. R. Soc. Lond. B 355, 1315-1320. doi: 10.1098/rstb.2000.0691

Crowley, B. E., Thorén, S., Rasoazanabary, E., Vogel, E. R., Barrett, M. A., Zohdy, S., et al. (2011). Explaining geographical variation in the isotope composition of mouse lemurs (Microcebus). J. Biogeogr. 38, 2106-2121. doi: 10.1111/j.13652699.2011.02551.x

Curcio, C. A., Sloan, K. R., Kalina, R. E., and Hendrickson, A. E. (1990). Human photoreceptor topography. J. Comp. Neurol. 292, 497-523. doi: $10.1002 / \mathrm{cne} .902920402$

Dagosto, M., Gebo, D. L., and Dolino, C. N. (2003). "The natural history of the Philippine tarsier (Tarsius syrichta)," in Tarsiers: Past, Present, and Future, eds P. C. Wright, E. L. Simons, and S. Gursky (New Brunswick: Rutgers University Press), 237-259.

Dahang, D., Severn, K., and Shekelle, M. (2008). "Eastern tarsiers in captivity, part II: A preliminary assessment of diet," in Primates of the Oriental Night, eds M. Shekelle, I. Maryanto, C. Groves, H. Schulze, and H. Fitch-Snyder (Jakarta: LIPI Press), 97-103.

Davis, D. D. (1962). Mammals of the lowland rain-forest of North Borneo. Bull. Natl. Mus. Singapore 31, 1-129.

DeNiro, M. J., and Epstein, S. (1978). Influence of diet on the distribution of carbon isotopes in animals. Geochim. Cosmochim. Acta 42, 495-506. doi: 10.1016/00167037(78)90199-90190

DeNiro, M. J., and Epstein, S. (1981). Influence of diet on the distribution of nitrogen isotopes in animals. Geochim. Cosmochim. Acta 45, 341-351. doi: 10.1016/0016 7037(81)90244-90241

Detwiler, S. R. (1941). The eye of the owl monkey (Nyctipithecus). Anat. Rec. 80, 233-241. doi: 10.1002/ar.1090800209

Dkhissi-Benyahya, O., Szel, A., Degrip, W. J., and Cooper, H. M. (2001). Short and mid-wavelength cone distribution in a nocturnal Strepsirrhine primate (Microcebus murinus). J. Comp. Neurol. 438, 490-504. doi: 10.1002/ cne. 1330

Elliot Smith, G. (1921). On examples of Tarsius from Sarawak. Proc. Zool. Soc. Lond. 91, 184-186. doi: 10.1111/j.1096-3642.1921.tb03257.x

Elliot Smith, G. (1928). The Bowman Lecture, 1928: the new vision. Trans Ophthalmol. Soc. UK 48, 64-85.

Ferraz de Oliveira, L., and Ripps, H. (1968). The "area centralis" of the owl monkey (Aotes trivirgatus). Vision Res. 8, 223-228. doi: 10.1016/0042-6989(68)9001090012

Finlay, B. L., Franco, E. C. S., Yamada, E. S., Crowley, J. C., Parsons, M., Muniz, J. A. P. C., etal. (2008). Number and topography of cones, rods and optic nerve axons in New and Old World primates. Vis. Neurosci. 25, 289-299. doi: $10.1017 /$ S0952523808080371

Fitch-Snyder, H. M. (2003). "History of captive conservation of tarsiers," in Tarsiers: Past, Present, and Future, eds P. C. Wright, E. L. Simons, and S. Gursky (New Brunswick: Rutgers University Press), 277-295.

Fite, K. V. (1973). Anatomical and behavioral correlates of visual acuity in the great horned owl. Vision Res. 13, 219-230. doi: 10.1016/0042-6989(73)90101-6

Fite, K. V., and Rosenfield-Wessels, S. (1975). A comparative study of deep avian foveas. Brain Behav. Evol. 12, 97-115. doi: 10.1159/000124142

Fogden, M. P. L. (1974). "A preliminary field study of the western tarsier, Tarsius bancanus Horsfield," in Prosimian Biology, eds R. D. Martin, G. A. Doyle, and A. C. Walker (London: Gerald Duckworth), 151-165.

Fox-Dobbs, K., Bump, J. K., Peterson, R. O., Fox, D. L., and Koch, P. L. (2007). Carnivore-specific stable isotope variables and variation in the foraging ecology of modern and ancient wolf populations: case studies from Isle Royale, Minnesota, and La Brea. Can. J. Zool. 85, 458-471. doi: 10.1139/ Z07-018
Fox-Dobbs, K., Nelson, A. A., Koch, P. L., and Leonard, J. A. (2012). Faunal isotope records reveal trophic and nutrient dynamics in twentieth century Yellowstone grasslands. Biol. Lett. 8, 838-841. doi: 10.1098/rsbl.2012.0321

Francey, R. J., Allison, C. E., Etheridge, D. M., Trudinger, C. M., Enting, I. G., Leuenberger, M., et al. (1999). A 1000-year high precision record of $\delta^{13} \mathrm{C}$ in atmospheric $\mathrm{CO}_{2}$. Tellus B 51, 170-193. doi: 10.1034/j.1600-0889.1999.t01-100005.x

Gannes, L. Z., O’Brien, D. M., and Martínez Del Rio, C. (1997). Stable isotopes in animal ecology: assumptions, caveats, and a call for more laboratory experiments. Ecology 78, 1271-1276. doi: 10.1890/00129658(1997)078[1271:SIIAEA]2.0.CO;2

Gursky, S. (2000). Effect of seasonality on the behavior of an insectivorous primate, Tarsius spectrum. Int. J. Primatol. 21, 477-495. doi: 10.1023/A:1005444020059

Gursky, S. (2002). The behavioral ecology of the spectral tarsier, Tarsius spectrum. Evol. Anthropol. 11, 226-234. doi: 10.1002/evan.10035

Gursky, S. (2003a). Predation experiments on infant spectral tarsiers (Tarsius spectrum). Folia Primatol. 74, 272-284. doi: 10.1159/000073314

Gursky, S. (2003b). Lunar philia in a nocturnal primate. Int. J. Primatol. 24, 351-367. doi: 10.1023/A:1023053301059

Gursky, S. L. (2007a). The Spectral Tarsier. Upper Saddle River: Pearson Education.

Gursky, S. L. (2007b). “The response of spectral tarsiers toward avian and terrestrial predators," in Primate Anti-predator Strategies, eds S. L. Gursky and K. A. I. Nekaris (New York: Springer), 241-252.

Hall, M. I. (2008). The anatomical relationships between the avian eye, orbit and sclerotic ring: implications for inferring activity patterns in extinct birds. J. Anat. 212, 781-794. doi: 10.1111/j.1469-7580.2008.00897.x

Hall, M. I., and Ross, C. F. (2007). Eye shape and activity pattern in birds. J. Zool. 271, 437-444. doi: 10.1111/j.1469-7998.2006.00227.x

Haring, D. M., and Wright, P. C. (1989). Hand-raising a Philippine tarsier, Tarsius syrichta. Zoo Biol. 8, 265-274. doi: 10.1002/zoo.1430080307

Harmening, W. M., and Wagner, H. (2011). From optics to attention: visual perception in barn owls. J. Comp. Physiol. A 197, 1031-1042. doi: 10.1007/s00359011-0664-663

Harrison, B. (1963). Trying to breed Tarsius. Malay. Nat. J. 17, 218-231.

Heaton, T. H. E. (1999). Spatial, species, and temporal variations in the ${ }^{13} \mathrm{C} /{ }^{12} \mathrm{C}$ ratios of $\mathrm{C}_{3}$ plants: implications for palaeodiet studies. J. Archaeol. Sci. 26, 637649. doi: 10.1006/jasc.1998.0381

Heffner, R. S., and Heffner, H. E. (1992). "Evolution of sound localization in mammals," in The Evolutionary Biology of Hearing, eds D. B. Webster, R. R. Fay, and A. N. Popper (New York: Springer), 691-715. doi: 10.1007/978-1-4612-2784-7_43

Hendrickson, A. (2005). "Organization of the adult primate fovea," in Macular Degeneration, eds P. L. Penfold and J. M. Provis (Berlin: Springer), 1-23. doi: 10.1007/3-540-26977-0_1

Hendrickson, A., Djajadi, H. R., Nakamura, L., Possin, D. E., and Sajuthi, D. (2000). Nocturnal tarsier retina has both short and long/medium-wavelength cones in an unusual topography. J. Comp. Neurol. 424, 718-730. doi: 10.1002/10969861(20000904)424:4<718::aid-cne12>3.0.co;2-z

Hietz, P., Turner, B. L., Wanek, W., Richter, A., Nock, C. A., and Wright, S. J. (2011). Long-term change in the nitrogen cycle of tropical forests. Science 334, 664-666. doi: $10.1126 /$ science. 1211979

Hoffmann, J. N., Montag, A. G., and Dominy, N. J. (2004). Meissner corpuscles and somatosensory acuity: the prehensile appendages of primates and elephants. Anat. Rec. A 281, 1138-1147. doi: 10.1002/ar.a.20119

Högberg, P. (1997). Tansley Review No. 95: ${ }^{15} \mathrm{~N}$ natural abundance in soil-plant systems. New Phytol. 137, 179-203. doi: 10.1046/j.1469-8137.1997.00808.x

Hyodo, F., Matsumoto, T., Takematsu, Y., Kamoi, T., Fukuda, D., Nakagawa, M., et al. (2010). The structure of a food web in a tropical rain forest in Malaysia based on carbon and nitrogen stable isotope ratios. J. Trop. Ecol. 26, 205-214. doi: 10.1017/S0266467409990502

Indermühle, A., Stocker, T. F., Joos, F., Fischer, H., Smith, H. J., Wahlen, M., et al. (1999). Holocene carbon-cycle dynamics based on $\mathrm{CO}_{2}$ trapped in ice at Taylor Dome, Antarctica. Nature 398, 121-126. doi: 10.1038/18158

Inzunza, O., Bravo, H., and Smith, R. L. (1989). Foveal regions of bird retinas correlate with the aster of the inner nuclear layer. Anat. Rec. 223, 342-346. doi: 10.1002/ar.1092230313

Jablonski, N. G. (2003). "The evolution of the tarsiid niche," in Tarsiers: Past, Present, and future, eds P. C. Wright, E. L. Simons, and S. Gursky. (New Brunswick: Rutgers University Press), 35-49. 
Jacobs, G. H., Neitz, M., and Neitz, J. (1996). Mutations in S-cone pigment genes and the absence of colour vision in two species of nocturnal primate. Proc. R. Soc. Lond. B 263, 705-710. doi: 10.1098/rspb.1996.0105

Joffe, B., Peichl, L., Hendrickson, A., Leonhardt, H., and Solovei, I. (2014). Diurnality and nocturnality in primates: an analysis from the rod photoreceptor nuclei perspective. Evol. Biol. 41, 1-11. doi: 10.1007/s11692-013-9240-9249

Jones, A. E. (1965). The retinal structure of (Aotes trivirgatus) the owl monkey. J. Comp. Neurol. 125, 19-27. doi: 10.1002/cne.901250104

Kawamura, S., and Kubotera, N. (2004). Ancestral loss of short wave-sensitive cone visual pigment in lorisiform prosimians, contrasting with its strict conservation in other prosimians. J. Mol. Evol. 58, 314-321. doi: 10.1007/s00239-0032553-z

Kawanishi, K., Liang, S. H. N., Darimont, C., Reimchen, T. E., and Sunquist, M. E. (2012). Isotopic niche differentiation among mammals from a rainforest in Peninsular Malaysia. Raffles Bull. Zool. 60, 233-239.

Kay, R. F., Campbell, V. M., Rossie, J. B., Colbert, M. W., and Rowe, T. B. (2004) Olfactory fossa of Tremacebus harringtoni (Platyrrhini, early Miocene, Sacanana Argentina): implications for activity pattern. Anat. Rec. A 281, 1157-1172. doi: 10.1002/ar.a.20121

Kay, R. F., and Kirk, E. C. (2000). Osteological evidence for the evolution of activity pattern and visual acuity in primates. Am. J. Phys. Anthropol. 113, 235-262. doi: 10.1002/1096-8644(200010) 113:2<235::aid-ajpa7>3.0.co;2-9

Keeling, C. D., Bollenbacher, A. F., and Whorf, T. P. (2005). "Monthly atmospheric ${ }^{13} \mathrm{C} /{ }^{12} \mathrm{C}$ isotopic ratios for $10 \mathrm{SIO}$ stations," in Trends - A Compendium of Data on Global Change. Oak Ridge, TN. Available at: cdiac.ornl.gov/trends/trends.htm

Kendall, C., Elliott, E. M., and Wankel, S. D. (2007). "Tracing anthropogenic inputs of nitrogen to ecosystems," in Stable Isotopes in Ecology and Environmental Science, 2nd Edn, eds R. Michener and K. Lajtha (Malden, MA: Blackwell), 375-449. doi: 10.1002/9780470691854.ch12

Kirk, E. C. (2006). Effects of activity pattern on eye size and orbital aperture size in primates. J. Hum. Evol. 51, 159-170. doi: 10.1016/j.jhevol.2006.02.004

Kitayama, K., and Iwamoto, K. (2001). Patterns of natural ${ }^{15} \mathrm{~N}$ abundance in the leaf-to-soil continuum of tropical rain forests differing in $\mathrm{N}$ availability on Mount Kinabalu, Borneo. Plant Soil 229, 203-212. doi: 10.1023/A:10048539 15544

Knudsen, E. I. (1994). Supervised learning in the brain. J. Neurosci. 14, 3985-3997.

Knudsen, E. I. (2002). Instructed learning in the auditory localization pathway of the barn owl. Nature 417, 322-328. doi:10.1038/417322a

Knudsen, E. I., and Knudsen, P. F. (1985). Vision guides the adjustment of auditory localization in young barn owls. Science 230, 545-548. doi: 10.1126/science. 4048948

Kohn, M. J. (2010). Carbon isotope compositions of terrestrial C3 plants as indicators of (paleo)ecology and (paleo)climate. Proc. Natl. Acad. Sci. U.S.A. 107, 19691-19695. doi: 10.1073/pnas.1004933107

Kolmer, W. (1930). Zur kenntnis des auges der primaten. Z. Anat. Entwicklungs. 93, 679-722. doi: 10.1007/bf02118055

König, C., and Weick, F. (2008). Owls of the World, 2nd Edn. New Haven: Yale University Press.

Le Gros Clark, W. E. (1959). The Antecedents of Man. Edinburgh: Edinburgh University Press.

Levenson, D. H., Fernandez-Duque, E., Evans, S., and Jacobs, G. H. (2007). Mutational changes in S-cone opsin genes common to both nocturnal and cathemeral Aotus monkeys. Am. J. Primatol. 69, 757-765. doi: 10.1002/ajp.20402

Lisney, T. J., Iwaniuk, A. N., Bandet, M. V., and Wylie, D. R. (2012). Eye shape and retinal topography in owls (Aves: Strigiformes). Brain Behav. Evol. 79, 218-236. doi: $10.1159 / 000337760$

Locket, N. A. (1992). Problems of deep foveas. Aust. N. Z. J. Ophthalmol. 20, 281-295. doi: 10.1111/j.1442-9071.1992.tb00740.x

Lok, A. F. S. L., Lee, T. K., and Lim, K. C. (2009). The biology of Otus lempiji cnephaues Deignan, the Sunda scops-owl in Singapore. Nat. Singapore 2, 31-38.

Long, E., Sweitzer, R., Diefenbach, D., and Ben-David, M. (2005). Controlling for anthropogenically induced atmospheric variation in stable carbon isotope studies. Oecologia 146, 148-156. doi: 10.1007/s00442-005-0181-186

MacKinnon, J., and MacKinnon, K. (1980). The behavior of wild spectral tarsiers Int. J. Primatol. 1, 361-379. doi: 10.1007/bf02692280

Mancini, F., Sambo, C. F., Ramirez, J. D., Bennett, D. L. H., Haggard, P., and Iannetti, G. D. (2013). A fovea for pain at the fingertips. Curr. Biol. 23, 496-500. doi: 10.1016/j.cub.2013.02.008
Marshall, J. D., Brooks, J. R., and Lajtha, K. (2007). "Sources of variation in the stable isotopic composition of plants," in Stable Isotopes in Ecology and Environmental Science, 2nd Edn, eds R. Michener and K. Lajtha (Boston: Wiley-Blackwell), 22-60. doi: 10.1002/9780470691854.ch2

Martin, G. R., and Gordon, I. E. (1974). Visual acuity in the tawny owl (Strix aluco). Vision Res. 14, 1393-1397. doi: 10.1016/0042-6989(74)90014-5

Martin, R. D. (1990). Primate Origins and Evolution: A Phylogenetic Reconstruction. Princeton: Princeton University Press.

Martin, R. D., and Ross, C. F. (2005). "The evolutionary and ecological context of primate vision," in The Primate Visual System: A Comparative Approach, ed. J. Kremers (Chichester: John Wiley \& Sons), 1-36.

Medina, E., and Minchin, P. (1980). Stratification of $\delta^{13} \mathrm{C}$ values of leaves in Amazonian rain forests. Oecologia 45, 377-378. doi: 10.1007/BF00540209

Melin, A. D., Matsushita, Y., Moritz, G. L., Dominy, N. J., and Kawamura, S. (2013). Inferred L/M cone opsin polymorphism of ancestral tarsiers sheds dim light on the origin of anthropoid primates. Proc. R. Soc. B 280, 20130189. doi: 10.1098/rspb.2013.0189

Melin, A. D., Moritz, G. L., Fosbury, R. A. E., Kawamura, S., and Dominy, N. J. (2012). Why aye-ayes see blue. Am. J. Primatol. 74, 185-192. doi: 10.1002/ajp.21996

Menegaz, R. A., and Kirk, E. C. (2009). Septa and processes: convergent evolution of the orbit in haplorhine primates and strigiform birds. J. Hum. Evol. 57, 672-687. doi: 10.1016/j.jhevol.2009.04.010

Menezes, A. N., Bonvicino, C. R., and Seuánez, H. N. (2010). Identification, classification and evolution of owl monkeys (Aotus, Illiger 1811). BMC Evol. Biol. 10:248. doi: 10.1186/1471-2148-10-248

Moore, B. A., Kamilar, J. M., Collin, S. P., Bininda-Emonds, O. R. P., Dominy, N. J., Hall, M. I., et al. (2012). A novel method for comparative analysis of retinal specialization traits from topographic maps. J. Vis. 12, 1-24. doi: 10.1167/12.12.13

Moritz, G. L., Lim, N. T.-L., Neitz, M., Peichl, L., and Dominy, N. J. (2013). Expression and evolution of short wavelength sensitive opsins in colugos: a nocturnal lineage that informs debate on primate origins. Evol. Biol. 40, 542-553. doi: 10.1007/s11692-013-9230-y

Nakagawa, M., Hyodo, F., and Nakashizuka, T. (2007). Effect of forest use on trophic levels of small mammals: an analysis using stable isotopes. Can. J. Zool. 85, 472-478. doi: 10.1139/Z07-026

Neuweiler, G. (2003). Evolutionary aspects of bat echolocation. J. Comp. Physiol. A 189, 245-256. doi: 10.1007/s00359-003-0406-402

Newsome, S. D., Martinez Del Rio, C., Bearhop, S., and Phillips, D. L. (2007). A niche for isotopic ecology. Front. Ecol. Environ. 5:429-436. doi: 10.1890/060150.1

Niemitz, C. (1979). "Outline of the behavior of Tarsius bancanus," in The Study of Prosimian Behaviour, eds G. A. Doyle and R. D. Martin (New York: Academic Press), 631-660.

Niemitz, C. (1984). "Synecological relationships and feeding behaviour of the genus Tarsius," in Biology of Tarsiers, ed. C. Niemitz (Stuttgart: Gustav Fischer Verlag), $59-75$.

Niemitz, C. (1985). Can a primate be an owl? - convergences in the same ecological niche. Forts. Zool. 30, 666-670.

Niemitz, C. (2010). Progreditur ordinara saltando et retrorsum... Normally proceeds in a leaping fashion, and backwards... Int. J. Primatol. 31, 941-957. doi: 10.1007/s10764-010-9454-y

Oehme, H. (1961). Vergleichend-histologische untersuchungen an der retina von eulen. Zoo Jb. Anat. 79, 439-478.

Ogden, T. E. (1994). "Ophthalmologic research in the owl monkey," in Aotus: The Owl Monkey, eds J. F. Baer, R. E. Weller, and I. Kakoma (San Diego: Academic Press), 263-286. doi: 10.1016/B978-0-12-072405-5.50015-9

O’Leary, M. H. (1988). Carbon isotopes in photosynthesis. Bioscience 38, 328-336. doi: $10.2307 / 1310735$

Parejo, D., Avilés, J. M., and Rodríguez, J. (2010). Visual cues and parental favouritism in a nocturnal bird. Biol. Lett. 6, 171-173. doi: 10.1098/rsbl.2009.0769 Peichl, L., Rakotondraparany, F., and Kappeler, P. (2001). Photoreceptor types and distributions in nocturnal and diurnal Malagasy primates. Invest. Ophthalmol. Vis. Sci. 42:S48.

Perelman, P., Johnson, W. E., Roos, C., Seuánez, H. N., Horvath, J. E., Moreira, M. A. M., et al. (2011). A molecular phylogeny of living primates. PLoS Genet. 7:e1001342. doi: 10.1371/journal.pgen.1001342

Perry, V. H., and Cowey, A. (1985). The ganglion cell and cone distributions in the monkey's retina: implications for central magnification factors. Vision Res. 25, 1795-1810. doi: 10.1016/0042-6989(85)90004-5 
Pettigrew, J. D., and Frost, B. J. (1985). A tactile fovea in the Scolopacidae? Brain Behav. Evol. 26, 185-195. doi: 10.1159/000118775

Polyak, S. (1957). The Vertebrate Visual System. Chicago: University of Chicago Press.

Post, D. M. (2002). Using stable isotopes to estimate trophic position: models, methods, and assumptions. Ecology 83, 703-718. doi: 10.1890/00129658(2002)083[0703:USITET]2.0.CO;2

Provis, J. M., Dubis, A. M., Maddess, T., and Carroll, J. (2013). Adaptation of the central retina for high acuity vision: cones, the fovea and the avascular zone. Prog. Retin. Eye Res. 35, 63-81. doi: 10.1016/j.preteyeres.2013.01.005

Ramsier, M. A., Cunningham, A. J., Moritz, G. L., Finneran, J. J., Williams, C. V., Ong, P. S., et al. (2012). Primate communication in the pure ultrasound. Biol. Lett. 8, 508-511. doi: 10.1098/rsbl.2011.1149

R Development Core Team. (2011). R: A Language and Environment for Statistical Computing. Vienna: R Foundation for Statistical Computing.

Rex, K., Michener, R., Kunz, T. H., and Voigt, C. C. (2011). Vertical stratification of neotropical leaf-nosed bats (Chiroptera: Phyllostomidae) revealed by stable carbon isotopes. J. Trop. Ecol. 27, 211-222. doi: 10.1017/S0266467411 000022

Roberts, M., and Kohn, F. (1993). Habitat use, foraging behavior, and activity patterns in reproducing western tarsiers, Tarsius bancanus, in captivity: a management synthesis. Zoo Biol. 12, 217-232. doi: 10.1002/zoo.14301 20207

Rochon-Duvigneaud, A. (1943). Les Yeux et la Vision des Vertébrés. Paris: Elsevier Masson.

Rohen, J. W., and Castenholz, A. (1967). Über die zentralisation der retina bei primaten. Folia Primatol. 5, 92-147. doi: 10.1159/000161941

Röll, B. (2001). Gecko vision - retinal organization, foveae and implications for binocular vision. Vision Res. 41, 2043-2056. doi: 10.1016/S0042-6989(01) 00093-91

Ross, C. F. (2000). Into the light: the origin of Anthropoidea. Annu. Rev. Anthropol. 29, 147-194. doi: 10.1146/annurev.anthro.29.1.147

Ross, C. F. (2004). "The tarsier fovea: functionless vestige on nocturnal adaptation?," in Anthropoid Origins: New Visions, eds C. F. Ross and R. F. Kay (New York: Kluwer Academic), 477-537.

Ross, C. F., Hall, I. M., and Heesy, C. P. (2007). "Were basal primates nocturnal? Evidence from eye and orbit shape," in Primate origins: Adaptations and Evolution, eds M. J. Ravosa and M. Dagosto (New York: Springer), 233-256.

Ross, C. F., and Kirk, E. C. (2007). Evolution of eye size and shape in primates. J. Hum. Evol. 52, 294-313. doi: 10.1016/j.jhevol.2006.09.006

Rossie, J. B., Ni, X., and Beard, K. C. (2006). Cranial remains of an Eocene tarsier. Proc. Natl. Acad. Sci. U.S.A. 103, 4381-4385. doi: 10.1073/pnas.0509424103

Roth, J. D., and Hobson, K. A. (2000). Stable carbon and nitrogen isotopic fractionation between diet and tissue of captive red fox: implications for dietary reconstruction. Can. J. Zool. 78, 848-852. doi: 10.1139/z00-008

Ruiz-García, M., Vásquez, C., Camargo, E., Leguizamón, N., Gálvez, H., Vallejo, A., et al. (2011). Molecular phylogenetics of Aotus (Platyrrhini, Cebidae). Int. J. Primatol. 32, 1218-1241. doi: 10.1007/s10764-011-9539-9532

Rutz, C., Bluff, L. A., Reed, N., Troscianko, J., Newton, J., Inger, R., et al. (2010). The ecological significance of tool use in New Caledonian crows. Science 329, 1523-1526. doi: 10.1126/science.1192053

Schoeninger, M. J. (1985). Trophic level effects on ${ }^{15} \mathrm{~N} /{ }^{14} \mathrm{~N}$ and ${ }^{13} \mathrm{C} /{ }^{12} \mathrm{C}$ ratios in bone collagen and strontium levels in bone mineral. J. Hum. Evol. 14, 515-525. doi: 10.1016/S0047-2484(85)80030-0

Schoeninger, M. J. (2010). "Toward a $\delta^{13} \mathrm{C}$ isoscape for primates," in Isoscapes: Understanding Movement, Pattern, and Process on Earth through Isotope Mapping, eds J. B. West, G. J. Bowen, T. E. Dawson, and K. P. Tu (New York: Springer), 319-333.

Silveira, L. C. L., Perry, V. H., and Yamada, E. S. (1993). The retinal ganglion cell distribution and the representation of the visual field in area 17 of the owl monkey, Aotus trivirgatus. Vis. Neurosci. 10, 887-897. doi: 10.1017/S095252380000609X

Silveira, L. C. L., Picanço-Diniz, C. W., Sampaio, L. F. S., and Oswaldo-Cruz, E. (1989). Retinal ganglion cell distribution in the cebus monkey: a comparison with the cortical magnification factors. Vision Res. 29, 1471-1483. doi: 10.1016/00426989(89)90131-4

Silveira, L. C. L., Yamada, E. S., Franco, E. C. S., and Finlay, B. L. (2001). The specialization of the owl monkey retina for night vision. Color Res. Appl. 26, S118-S122. doi: 10.1002/1520-6378(2001)26:1++>::AID-COL26>3.0.CO;2-9
Silveira, L. C. L., Yamada, E. S., Perry, V. H., and Picanço-Diniz, C. W. (1994). $\mathrm{M}$ and $\mathrm{P}$ retinal ganglion cells of diurnal, and nocturnal NewWorld monkeys. Neuroreport 5, 2077-2081. doi: 10.1097/00001756-19941027000022

Sponheimer, M., Robinson, T., Ayliffe, L., Roeder, B., Hammer, J., Passey, B., et al. (2003). Nitrogen isotopes in mammalian herbivores: hair $\delta^{15} \mathrm{~N}$ values from a controlled feeding study. Int. J. Osteoarchaeol. 13, 80-87. doi: 10.1002/oa.655

Springer, M. S., Meredith, R. W., Gatesy, J., Emerling, C. A., Park, J., Rabosky, D. L., et al. (2012). Macroevolutionary dynamics and historical biogeography of primate diversification inferred from a species supermatrix. PLOS ONE 7:e49521. doi: 10.1371/journal.pone.0049521

Steele, K. W., and Daniel, R. M. (1978). Fractionation of nitrogen isotopes by animals: a further complication to the use of variations in the natural abundance of ${ }^{15} \mathrm{~N}$ for tracer studies. J. Agric. Sci. 90, 7-9. doi: 10.1017/S00218596000 $4853 X$

Tan, Y., Yoder, A. D., Yamashita, N., and Li, W.-H. (2005). Evidence from opsin genes rejects nocturnality in ancestral primates. Proc. Natl. Acad. Sci. U.S.A. 102, 14712-14716. doi: 10.1073/pnas.0507042102

Tansley, K. (1960). The retina of a diurnal gecko, Phelsuma madagascariensis longinsulae. Pflügers Arch. Gesamte Physiol. Menschen Tiere 272, 262-269. doi: 10.1007/BF00363014

Tetreault, N., Hakeem, A., and Allman, J. M. (2004). "The distribution and size of retinal ganglion cells in Microcebus murinus, Cheirogaleus medius, and Tarsius syrichta: implications for the evolution of sensory systems in primates," in Anthropoid Origins: New Visions, eds C. F. Ross and R. F. Kay (New York: Kluwer Academic/Plenum Publishers), 463-475.

Treacher Collins, E. (1922). Arboreal Life and the Evolution of the Human Eye. Philadelphia: Lea and Febiger.

Tremble, M., Muskita, Y., and Supriatna, J. (1993). Field observations of Tarsius dianae at Lore Lindu National Park, Central Sulawesi, Indonesia. Trop. Biodivers. $1,67-76$.

van der Merwe, N.J., and Medina, E. (1991). The canopy effect, carbon isotope ratios and foodwebs in Amazonia. J. Archaeol. Sci. 18, 249-259. doi: 10.1016/03054403(91)90064-V

Vogel, E. R., Knott, C. D., Crowley, B. E., Blakely, M. D., Larsen, M. D., and Dominy, N. J. (2012). Bornean orangutans on the brink of protein bankruptcy. Biol. Lett. 8, 333-336. doi: 10.1098/rsbl.2011.1040

Vogel, J. C. (1978). Recycling of $\mathrm{CO}_{2}$ in a forest environment. Oecolog. Plantar. 13, $89-94$.

Voigt, C. C. (2010). Insights into strata use of forest animals using the 'canopy effect'. Biotropica 42, 634-637. doi: 10.1111/j.1744-7429.2010.00703.x

Walls, G. L. (1937). Significance of the foveal depression. Arch. Ophthalmol. 18, 912-919. doi: 10.1001/archopht.1937.00850120046005

Walls, G. L. (1942). The Vertebrate Eye and its Adaptive Radiation. Bloomfield Hills, MI: Cranbrook Institute of Science. doi: 10.5962/bhl.title.7369

Walls, G. L. (1953). The Lateral Geniculate Nucleus and Visual Histophysiology. Berkeley: University of California Press.

Wathey, J. C., and Pettigrew, J. D. (1989). Quantitative analysis of the retinal ganglion cell layer and optic nerve of the barn owl Tyto alba. Brain Behav. Evol. 33, 279-292. doi: $10.1159 / 000115936$

Weale, R. A. (1966). Why does the human retina possess a fovea? Nature 212, 255-256. doi: 10.1038/212255a0

Webb, S. V., and Kaas, J. H. (1976). The sizes and distribution of ganglion cells in the retina of the owl monkey, Aotus trivirgatus. Vision Res. 16, 1247-1254. doi: 10.1016/0042-6989(76)90049-3

Wharton, C. H. (1950). The tarsier in captivity. J. Mammal. 31, 260-268. doi: $10.2307 / 1375291$

Wikler, K. C., and Rakic, P. (1990). Distribution of photoreceptor subtypes in the retina of diurnal and nocturnal primates. J. Neurosci. 10, 3390-3401.

Wilder, H. D., Grünert, U., Lee, B. B., and Martin, P. R. (1996). Topography of ganglion cells and photoreceptors in the retina of a New World monkey: the marmoset Callithrix jacchus. Vis. Neurosci. 13, 335-352. doi: 10.1017/S0952523800 007586

Williams, B. A., Kay, R. F., and Kirk, E. C. (2010). New perspectives on anthropoid origins. Proc. Natl. Acad. Sci. U.S.A. 107, 4797-4804. doi: 10.1073/pnas.0908320107

Wolin, L. R., and Massopust, L. C. (1967). Characteristics of the ocular fundus in primates. J. Anat. 101, 693-699. 
Wolin, L. R., and Massopust, L. C. (1970). "Morphology of the primate retina," in The Primate Brain, eds C. R. Noback and W. Montagna (New York: AppletonCentury-Crofts), 1-27.

Wood, C. A. (1917). The Fundus Oculi of Birds Especially as Viewed by the Ophthalmoscope. Chicago: Lakeside Press. doi: 10.5962/bhl.title.63624

Woodcock, P., Edwards, D. P., Newton, R. J., Edwards, F. A., Khen, C. V., Bottrell, S. H., et al. (2012). Assessing trophic position from nitrogen isotope ratios: effective calibration against spatially varying baselines. Naturwissenschaften 99, 275-283. doi: 10.1007/s00114-012-0896-892

Woollard, H. H. (1925). The anatomy of Tarsius spectrum. Proc. Zool. Soc. Lond. 95, 1071-1184. doi: 10.1111/j.1469-7998.1925.tb07117.x

Woollard, H. H. (1926). Notes on the retina and lateral geniculate body in Tupaia, Tarsius, Nycticebus and Hapale. Brain 49, 77-104. doi: 10.1093/brain/ 49.1.77

Woollard, H. H. (1927). The differentiation of the retina in the primates. Proc. Zool. Soc. Lond. 97, 1-18. doi: 10.1111/j.1096-3642.1927.tb02243.x

Yamada, E. S., Silveira, L. C. L., Perry, V. H., and Franco, E. C. (2001). M and $\mathrm{P}$ retinal ganglion cells of the owl monkey: morphology, size and photoreceptor convergence. Vision Res. 41, 119-131. doi: 10.1016/S0042-6989(00) 00244-3
Yeakel, J. D., Patterson, B. D., Fox-Dobbs, K., Okumura, M. M., Cerling, T. E., Moore, J. W., et al. (2009). Cooperation and individuality among man-eating lions. Proc. Natl. Acad. Sci. U.S.A. 106, 19040-19043. doi: 10.1073/pnas.0905309106

Conflict of Interest Statement: The authors declare that the research was conducted in the absence of any commercial or financial relationships that could be construed as a potential conflict of interest.

Received: 25 March 2014; accepted: 08 July 2014; published online: 25 July 2014.

Citation: Moritz GL, Melin AD, Tuh Yit Yu F, Bernard H, Ong PS and Dominy NJ (2014) Niche convergence suggests functionality of the nocturnal fovea. Front. Integr. Neurosci. 8:61. doi: 10.3389/fnint.2014.00061

This article was submitted to the journal Frontiers in Integrative Neuroscience. Copyright (c) 2014 Moritz, Melin, Tuh Yit Yu, Bernard, Ong and Dominy. This is an open-access article distributed under the terms of the Creative Commons Attribution License (CC BY). The use, distribution or reproduction in other forums is permitted, provided the original author(s) or licensor are credited and that the original publication in this journal is cited, in accordance with accepted academic practice. No use, distribution or reproduction is permitted which does not comply with these terms. 